\title{
Feeding concentrates with different protein sources to high-yielding, mid-lactation Norwegian Red cows: Effect on cheese ripening
}

\author{
M. A. Olsen, ${ }^{1}$ S. G. Vhile, ${ }^{2}$ D. Porcellato, ${ }^{1}$ A. Kidane,${ }^{2}$ and S. B. Skeie ${ }^{1 *}$ \\ ${ }^{1}$ Faculty of Chemistry, Biotechnology and Food Science (KBM), Norwegian University of Life Sciences, PO Box 5003, N-1432 Ås, Norway \\ ${ }^{2}$ Faculty of Biosciences, Department of Animal and Aquacultural Sciences, Norwegian University of Life Sciences, PO Box 5003, N-1432 Ås, \\ Norway
}

\begin{abstract}
Soybean meal is one of the most important protein sources in concentrate feeds for dairy cows. The objective of the present study was to provide knowledge on the effects of using a novel yeast microbial protein source (Candida utilis) in concentrate feed for dairy cows on the production and quality of a Gouda-type cheese. Forty-eight Norwegian Red dairy cows in early to mid lactation were fed a basal diet of grass silage, which was supplemented with 3 different concentrate feeds. The protein source of the concentrates was based on conventional soybean meal (SBM), novel yeast $(C$. utilis; YEA), or barley (BAR; used as negative control because barley has a lower protein content). The experiment was carried out for a period of $10 \mathrm{wk}$, with the first $2 \mathrm{wk}$ as an adaptation period where all dairy cows were fed grass silage and the SBM concentrate. The cows were then randomly allocated to 1 of the 3 different compound feeds: SBM, yeast, or barley. Cheeses were made during wk 8 and 9 of the experiment, with 4 batches of cheese made from milk from each of the 3 groups. The cheeses made from milk from cows fed SBM concentrate (SBM cheese) had a higher content of DL-pyroglutamic acid and free amino acids than the other cheeses, indicating a faster ripening in the SBM cheeses. Despite these differences, the sensory properties, the microbiota, and the Lactococcus population at $15 \mathrm{wk}$ of ripening were not significantly different between the cheeses. This experiment showed that although the raw materials used in the concentrate feed clearly influenced the ripening of the cheeses, this did not affect cheese quality. Yeast $(C$. utilis) as a protein source in concentrate feed for dairy cows can be used as a replacement for soybean meal without compromising the quality of Norwegian Gouda-type cheeses.
\end{abstract}

Received July 6, 2020.

Accepted November 4, 2020.

*Corresponding author: siv.skeie@nmbu.no
Key words: novel concentrate feed, cheese ripening, cheese quality

\section{INTRODUCTION}

The feed industry needs to develop novel, sustainable, nonfood protein sources to increase food security and to have more choices in an unpredictable future. Due to limited cultivatable land and a challenging climate, there is a shortage of nationally produced protein feed sources in countries above approximately $55^{\circ} \mathrm{N}$, which necessitates the import of protein-rich feed ingredients (de Visser et al., 2014; Øverland and Skrede, 2017). Diets for high-yielding dairy cows in Norway commonly consist of grass silage and concentrates at a ratio of 60/40 (Animalia, 2019). Today, it is difficult to locally produce sufficient amounts of protein from grass silage and cereals such as barley to cover the nutritional needs of high-yielding dairy cows. The Norwegian dairy industry therefore needs to find novel and alternative protein sources that can be added as a supplement to barley in feed concentrates.

Around $75 \%$ of the soy produced worldwide (measured by weight) is used as feed for livestock (FCRN Foodsource, 2020). Because the world's population is expected to increase to 9.8 billion people by 2050 (United Nations, 2017), this is not an optimal use of soy protein. Soybeans are rich in protein, making them an excellent protein source for human nutrition. However, the feed influences the milk composition (Sutton, 1989) and, therefore, most likely the cheese quality. Several studies have evaluated the effect of different protein sources used in feed for dairy cows on milk and cheese quality; however, none of these studies used yeast as a protein source in the feed. Sankarlal et al. (2015) fed dried distillers grains at 0,10 , and $20 \%$ of a TMR diet to mid-lactation Holstein cows and found an increase in long-chain unsaturated fatty acids and a decrease in most medium-chain and all short-chain fatty acids in Baby Swiss cheeses. Testroet et al. (2018) compared 2 different isonitrogenous and isoenergetic diets given to 
mid-lactation Holstein cows: a diet containing 13.5\% of DM from soybean meal versus $19.5 \%$ of DM from reduced-fat dried distillers grains. They found no differences in the suitability of milk for cheese making (Baby Swiss cheese), as the quality of the produced cheeses was similar. Ferreira et al. (2017) studied the effect of partially replacing ground corn and soybean meal with licuri cake (a biodiesel by-product) at different concentrations $(0,200,400$, and $600 \mathrm{~g} / \mathrm{kg}$ in DM). They reported a linear increase in milk fat concentration, which resulted in a higher fat content in the Minas Frescal cheese. They observed no differences between the feeds in relation to yield, protein, lactose, total solids, and solids nonfat in either the milk or the cheese.

Innovative methods are needed to increase national self-sufficiency of livestock feed and to reallocate nutritious soy protein from feed to food protein. Recent developments in biorefining technologies have made it possible to produce yeast biomass by fermentation of sugars derived from lignocellulosic biomass, such as spruce wood (Øverland and Skrede, 2017; Lapeña et al., 2020), where enzyme technology has been used to convert the cellulose and hemicellulose into sugars. Today, single-cell protein from yeast, bacteria, and algae are obtained by commercially growing them on molasses from different sources (e.g., sugar cane, sugar beets, corn). It is, however, possible to use by-products from agriculture and raw materials from forestry. Many countries have substantial areas of forest that traditionally have been of low value as feed for livestock. Forested areas in Norway account for $37.4 \%$ of the mainland (Statistisk Sentralbyrå, 2019) and therefore represent a large bioresource. Production of biomass from wood may make it possible in the future for the livestock industry in areas with low self-sufficiency of protein-rich feed to use locally produced nonfood protein sources such as yeast in animal feed.

Several studies investigated the effect of yeast as a protein source in feed for dairy cows on feed efficiency, milk yield, and the metabolic status of the cow (Sabbia et al., 2012; Neal et al., 2014; Manthey et al., 2016). No clear differences in milk composition could be attributed to the different feed treatments. However, these studies have only to a minor extent focused on whether use of yeast influences milk quality more extensively than the crude milk composition. To our knowledge, products made from such milk (i.e., cheese) have not been studied. About $37.7 \%$ of milk is processed into cheese in the European Union (Eurostat, 2019). Therefore, there is a need to ensure that the use of novel yeast microbial protein sources for concentrate feed for dairy cows does not compromise the production and quality of cheese. The objective of this study was to compare the effect of a novel concentrate feed for dairy cows based on yeast (Candida utilis) with a conventional concentrate feed based on soybean meal or barley on the quality of a Gouda-type cheese.

\section{MATERIALS AND METHODS}

\section{Animals, Feed Composition, and Feeding Regimens}

The feeding experiment was performed at the Animal Production and Experimental Unit at the Norwegian University of Life Sciences (Ås, Norway). All animal procedures were approved by the national animal research authority of the Norwegian Food Safety Authority (FOTS ID 18038).

Forty-eight Norwegian Red dairy cows in early to mid lactation were allocated into 3 treatment groups with 16 replicates per treatment based on parity, milk yield at start of the experiment, DIM, and milk protein genetic variants. An overview of the milk protein genetic variants is shown in Table 1. Milk samples from each individual cow were collected in wk 7 and analyzed for SCC by flow cytometry (Bentley Instruments, Chaska, $\mathrm{MN})$. The feeding experiment lasted for $10 \mathrm{wk}$ whereby the first $2 \mathrm{wk}$ were an adaptation period and during the remaining 8 wk the cows were given the experimental diets (cheesemaking was done in wk 6 and 7 of the experimental period).

Table 1. Milk protein genetic variants (no. $)^{1}$

\begin{tabular}{lrrr}
\hline Protein and genotype & BAR & SBM & YEA \\
\hline$\alpha_{\text {S1-CN }}$ & 10 & 14 & 11 \\
BB & 5 & 2 & 5 \\
BC & 1 & 0 & 0 \\
CC & & & \\
$\beta-C N$ & 0 & 1 & 1 \\
A1A1 & 12 & 8 & 10 \\
A2A2 & 0 & 0 & 1 \\
A2B & 4 & 7 & 4 \\
A1A2 & & & \\
K-CN & 0 & 1 & 1 \\
BB & 0 & 1 & 1 \\
HH & 14 & 12 & 9 \\
AA & 1 & 1 & 3 \\
AE & 1 & 1 & 2 \\
AB & & & \\
$\beta-L G$ & 6 & 9 & 6 \\
BB & 8 & 4 & 8 \\
AB & 1 & 1 & 1 \\
AA & 1 & 2 & 1 \\
Unknown & & & \\
\hline
\end{tabular}

${ }^{1}$ The experiment was carried out for a period of $10 \mathrm{wk}$, with the first 2 wk as an adaptation period where all dairy cows were fed grass silage and soybean meal (SBM) concentrate. The cows were then randomly allocated to 1 of the 3 different compound feeds: SBM $(\mathrm{n}=16)$, novel yeast (Candida utilis; YEA; $\mathrm{n}=16$ ), or barley (BAR; $\mathrm{n}=16$ ). 
During the entire experiment, the cows had free access to good-quality grass silage from individual automatic feeders. Mean daily silage DMI was $14.5 \mathrm{~kg} / \mathrm{cow}$ during the experimental period. During the 2 -wk adaption period, cows in all 3 treatment groups were fed the soybean meal (SBM) concentrate feed. During the experimental period ( $8 \mathrm{wk})$, the cows in each treatment group received concentrate feed prepared with SBM (as in the adaption period), C. utilis (YEA), or barley (BAR; negative control diet where soybean meal or yeast were replaced by barley, which has a lower protein content).

The amount of concentrate feed for each individual cow was calculated using the Nordic feeding standard (Volden, 2011). This was on average $7.7 \mathrm{~kg}$ of $\mathrm{DM} /$ cow per day during the experimental period. The daily portions of the concentrate feed were fed from automatic feeders on split portions with a maximum of $4 \mathrm{~kg} / \mathrm{cow}$ per visit.

\section{Characterization of the Experimental Feeds}

The chemical composition of the basal diet (grass silage) and concentrate feed is provided in Table 2 . The experimental concentrate feeds were prepared in such a way that the SBM and YEA were iso-proteinaceous and all 3 feeds were roughly iso-energetic. This was achieved by substituting yeast and barley for the soybean meal in the respective diets. The $C$. utilis used in this experiment was produced by Danstar Ferment (Fredericia, Denmark) with sugar cane molasses as the growth medium.

\section{Collection of Milk and Cheese Making}

Cheeses were made during wk 8 and 9 of the feeding experiment. The cows were milked by a milking robot system (De Laval, Lund, Sweden), and the milk from the specific cows of each group (SBM, BAR, and YEA) was collected in a separate milk tank over $2 \mathrm{~d}$.

It was only possible to sample milk from one experimental group at a time. Therefore, cheese was produced over 6 production days, 2 randomly selected days for each type of milk. At each production day, 2 vats of cheese were made and these were considered to be replicates. This resulted in 4 cheese vats produced from the same type of milk (SBM, BAR, or YEA); in total, 12 vats of cheese were made.

Full-fat Gouda-type cheese was produced using the method described by Porcellato and Skeie (2016) with minor adjustments. In short, cheeses were made from $300 \mathrm{~L}$ of pasteurized $\left(72^{\circ} \mathrm{C}\right.$ for $\left.15 \mathrm{~s}\right)$ milk (standardized to $2.7 \%$ fat). The milk was analyzed for fat, protein, casein, and lactose using a MilkoScan FT1 (Foss Elec-

Table 2. Information (DIM at start, milk yield at start, and parity) on the dairy cows distributed in the 3 diet groups and the composition of the 3 concentrate feeds

\begin{tabular}{|c|c|c|c|c|}
\hline \multirow[b]{2}{*}{ Item } & \multicolumn{3}{|c|}{ Concentrate feed $^{1}$} & \multirow{2}{*}{$\begin{array}{l}\text { Grass } \\
\text { silage }\end{array}$} \\
\hline & BAR & SBM & YEA & \\
\hline \multicolumn{5}{|l|}{ Cows $($ mean $\pm \mathrm{SD})$} \\
\hline DIM at start (wk 0) & $99.7 \pm 35.43$ & $101.2 \pm 31.48$ & $100.6 \pm 37.04$ & \\
\hline Milk yield at start (L/d) & $31.7 \pm 7.97$ & $30.2 \pm 7.61^{2}$ & $31.8 \pm 11.64^{2}$ & \\
\hline Parity & $1.7 \pm 0.95$ & $2.0 \pm 1.63$ & $1.7 \pm 0.98$ & \\
\hline $\mathrm{SCC}(\log$ cells $/ \mathrm{mL})$ & $4.44 \pm 0.40^{4}$ & $4.37 \pm 0.34^{5}$ & $4.64 \pm 0.68$ & \\
\hline \multicolumn{5}{|l|}{ Chemical composition $^{6}$} \\
\hline DM (g/kg) & 875.3 & 875.2 & 881.3 & 300 \\
\hline Ash $(\mathrm{g} / \mathrm{kg}$ of $\mathrm{DM})$ & 69.6 & 65.9 & 67.5 & 75.8 \\
\hline $\mathrm{CP}^{7}(\mathrm{~g} / \mathrm{kg}$ of $\mathrm{DM})$ & 133.9 & 161.1 & 156.5 & 181.4 \\
\hline $\mathrm{NDF}(\mathrm{g} / \mathrm{kg}$ of $\mathrm{DM})$ & 187.0 & 186.4 & 169.3 & 532.5 \\
\hline Starch $(\mathrm{g} / \mathrm{kg}$ of $\mathrm{DM})$ & 406.1 & 385.0 & 364.9 & - \\
\hline Fat $(\mathrm{g} / \mathrm{kg}$ of $\mathrm{DM})$ & 38.0 & 38.3 & 36.9 & 46.3 \\
\hline Water-soluble carbohydrate (\%) & 5.7 & 6.2 & 5.9 & 1.7 \\
\hline
\end{tabular}

${ }^{1}$ The experiment was carried out for a period of $10 \mathrm{wk}$, with the first $2 \mathrm{wk}$ as an adaptation period where all dairy cows were fed grass silage and soybean meal (SBM) concentrate. The cows were then randomly allocated to 1 of the 3 different compound feeds: SBM $(\mathrm{n}=16$ ), novel yeast (Candida utilis; YEA; $\mathrm{n}=16$ ), or barley $(\mathrm{BAR} ; \mathrm{n}=16)$.

${ }^{2} \mathrm{n}=15$ (milk yield not measured for $1 \mathrm{cow}$ ).

${ }^{3}$ The reported SCC is based on individual milk samples from wk 7 of the experiment.

${ }^{4} \mathrm{n}=14$ (2 cows were taken out of the experiment in wk 7-10).

${ }^{5} \mathrm{n}=15$ ( 1 cow was taken out of the experiment in wk $7-10$ ).

${ }^{6}$ The reported chemical composition is based on a minimum of 3 analyses on composite samples.

${ }^{7}$ Calculated as $\mathrm{N} \times 6.25$. 
tric A/S, Hillerød, Denmark). The bulk starter was prepared by inoculating a freeze-dried CHN-19 starter (Chr. Hansen, Hørsholm, Denmark) in UHT milk and incubated at $20^{\circ} \mathrm{C}$ for $20 \mathrm{~h}$. The cheese milk was inoculated with $1 \%$ (vol/vol) of the prepared starter. After $30 \mathrm{~min}$ of preripening at $32^{\circ} \mathrm{C}$, rennet (Chy-Max Plus, Chr. Hansen) was added at $25 \mathrm{~mL} / 100 \mathrm{~L}$ of milk. After cutting, the curd was stirred for 18 min before whey drainage and water addition, the temperature was increased for 10 min to a scalding temperature of $38^{\circ} \mathrm{C}$, and further scalding and stirring proceeded for $35 \mathrm{~min}$. Whey drainage was $40 \%$ (vol/vol) and water addition was $40 \%$ (vol/vol). After whey drainage and pressing, the cheeses were salted in saturated brine $(26 \%$, wt $/ w t)$ for $10 \mathrm{~h}$. The cheeses were ripened for $10 \mathrm{~d}$ at $11^{\circ} \mathrm{C}$ at 60 to $65 \% \mathrm{RH}$ and then for $14 \mathrm{~d}$ at $19^{\circ} \mathrm{C}$ at 65 to $70 \%$ $\mathrm{RH}$ before further ripening at $4^{\circ} \mathrm{C}$ until 15 wk. During the first $10 \mathrm{~d}$ of ripening, the cheeses were coated with 2 layers of Ceska-WL plastic emulsion containing 0.025\% natamycin (CSK Food Enrichment, Leeuwarden, the Netherlands). After $24 \mathrm{~d}$, when moved to the $4^{\circ} \mathrm{C}$ room, the cheeses were vacuum-packed in Cryovac cheese vacuum bags (Cryovac, Elmwood Park, NJ).

\section{Cheese Analysis}

Cheese was sampled according to IDF standard 50C (International Dairy Federation, 1995).

Chemical Analysis of Cheese. Cheese pH was measured using a PHM 92 Lab pH meter (Radiometer, Copenhagen, Denmark). Dry matter content was determined according to IDF standard 50C (International Dairy Federation, 1995). Grated cheese samples for analysis of free AA (FAA) were stored at $-20^{\circ} \mathrm{C}$ until analysis by HPLC as described by Martinovic et al. (2013). Quantification of organic acids and carbohydrates was done by HPLC, according to a method described by Skeie et al. (2008). Total protein was determined according to IDF standard 20B (International Dairy Federation, 1993). The citrate water slurry used for determination of total protein was analyzed by capillary electrophoresis as described previously (Jørgensen et al., 2016; Ketto et al., 2017) using an Agilent G1600AX equipped with Agilent ChemStation software (Agilent Technologies, Waldbronn, Germany).

Sensory Analysis. Descriptive analysis of the cheeses was performed when the cheeses were between 11 and 13 wk by a panel of 6 trained assessors, according to the method described by Kraggerud et al. (2008). The analysis followed ISO standards 8589, 5492, and 4121 (ISO, 1988, 1992, 2003, respectively) for the design of the test room, vocabulary, and response scale (1-9), respectively. The means between the panelists for each attribute were used in further calculations.

\section{Statistical Analysis}

Significant effects $(P<0.05)$ of the experimental factors for all responses (outside of the microbiota data) were found using the SAS Mixed models procedure (SAS Institute Inc., Cary, NC). Feed was used as the main factor $(n=3)$ and cheesemaking day $(n=6)$ as a random factor. A least squares post hoc test (Tukey) was used to test differences between means (all pairwise differences).

Principal component analysis (PCA) of the organic acids, FAA, and sensory profiling data was performed using The Unscrambler X version 10.4 (https://www .camo.com/unscramblersuite/). The data (except for the sensory data) were weighted by dividing each response variable by the standard deviation of the variable.

Statistical analysis of the microbiota data was done similarly to that described by Skeie et al. (2019). Briefly, the sequence variants tables were normalized using the cumulative-sum scaling method using the $\mathrm{R}$ package "metagenomeSeq" (Paulson et al., 2013). Permutational multivariate ANOVA between the cheeses in the different diet groups was performed using the Bray-Curtis dissimilarity matrixes (no. of permutations = 999). The nonmetric multidimensional scaling was chosen as ordination method using the Bray-Curtis distance matrix.

\section{RESULTS}

\section{Gross Composition of Cheese Milk and Cheese}

Gross composition of fat-standardized cheese milk and cheese is shown in Table 3 . The casein content of the cheese milk was significantly $(P=0.0005)$ influenced by the concentrate feed, whereby the BAR milk showed a lower casein content than the YEA and SBM milks. The difference in casein content led to a significantly higher rennet-to-casein ratio in the BAR cheese milk compared with the YEA and SBM cheese milks.

After 15 wk of ripening, only minor compositional differences were found between the cheeses. Although not significant, the SBM cheese had a higher average number of viable presumptive lactococci counts (log) on M17 agar compared with the BAR and YEA cheeses.

\section{Organic Acids}

Principal components analysis of the organic acids present in the cheeses after $15 \mathrm{wk}$ of ripening (Figure 1) showed that the SBM and YEA cheeses were located opposite each other along principal component 1 with a higher content of orotic acid and DL-pyroglutamic 
cheeses, and most of the taste and smell attributes were clustered in the middle near origo and thereby did not explain any of the variation between the cheeses. Most of the YEA cheeses were associated with a pasty texture, whereas the SBM and BAR cheeses were more associated with a grainy texture.

\section{Microbiota After 15 wk of Ripening}

Analysis of the cheese microbiota after 15 wk of ripening showed that the cheeses were not significantly different with respect to the source of feed (Adonis $P$-value $=0.483)$. The main genus identified was Lactococcus (98.3\% of all the reads) followed by Lactobacillus (1\%) and Leuconostoc (0.15\%). The Lactococcus population (as sequenced by the epsD gene) identified 22 sequence variants with abundance greater than $0.3 \%$, and no significant influence of the feed was found on the composition of the Lactococcus population after 15 wk of ripening (Adonis $P$-value $=0.424$ ). Nonmetric multidimensional scaling did not show any clear clustering of the samples with regards to the microbiota, and although small differences in Lactococcus population composition were detected between the BAR and SBM feeds, no significant differences between the groups was detected (Figure 5).

\section{DISCUSSION}

Concentrate feeds based on 3 different protein sources (BAR, SBM, and YEA) were fed to 48 mid-lactation
Norwegian Red cows during a period of 10 wk. Goudatype cheeses were made during wk 8 and 9 of the feeding experiment.

The capillary electrophoresis uncovered differences in protein composition and degradation during ripening between the cheeses. However, although the cows were grouped to balance the genetic variants, we did not succeed completely and the grouping became somewhat unbalanced with some differences between the experimental groups. The SBM group contained more A1 cows than the BAR and YEA groups. These differences might explain some of the differences between the cheeses as observed by capillary electrophoresis. Although the BAR cows showed the lowest prevalence of the $\beta-\mathrm{CN}$ A1 allele, the BAR cheeses had the highest peak of intact $\beta$-CN A1 after 15 wk of ripening, showing a much lower degradation of $\beta-\mathrm{CN}$ A1. The BAR cows showed the highest prevalence of the $\beta-\mathrm{CN}$ A2 allele, but the peak height of intact $\beta-\mathrm{CN}$ A2 did not differ between the cheeses of the different experimental groups. However, BAR cheeses had a higher peak of $\gamma_{1^{-}}$ CN A2, and one possible explanation could be that the degradation of $\beta-\mathrm{CN}$ A2 was faster in the BAR cheeses. The SBM cheeses showed higher peaks of intact $\alpha_{\mathrm{S} 1}-\mathrm{CN}$ $8 \mathrm{P}$ and $9 \mathrm{P}$, and because the rennet-to-casein ratio was lowest in this cheese (although not significantly different from the YEA cheese), a lower retention of rennet and hence a lower rennet activity could be expected in the SBM cheeses (Fox et al., 2017). This could further lead to a lower degradation of $\alpha_{\mathrm{S}_{1}}-\mathrm{CN}$ in the SBM cheeses as observed in this experiment. Therefore, if the rennet-



Figure 1. Principal component analysis of organic acids in cheeses ripened for 15 wk. The letter represents the concentrate feed treatment ( $\mathrm{B}=$ barley; $\mathrm{Y}=$ yeast; $\mathrm{S}=$ soybean meal), and the number after each letter indicates which replicate (cheeses 1 and 2 within the same diet group were made on cheesemaking d 1, and cheeses 3 and 4 were made on cheesemaking d 2). Principal components (PC) 1 and 2 explain 55 and $34 \%$ of the variation, respectively. The experimental groups are outlined. 


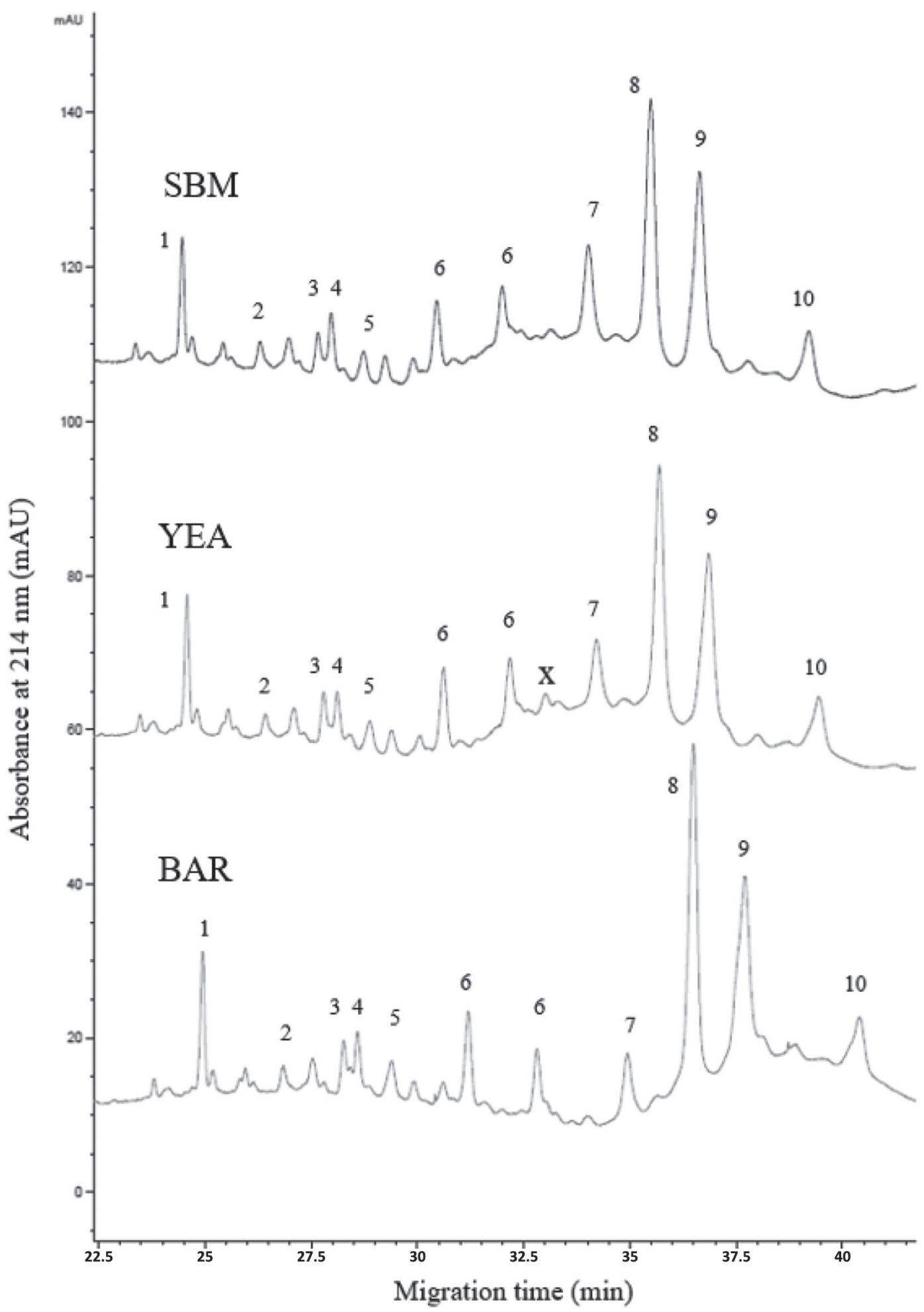

Figure 2. Protein profiles of cheeses after $15 \mathrm{wk}$ of ripening representing the 3 diet groups $(\mathrm{BAR}=$ barley; YEA $=$ yeast; SBM $=$ soybean meal) analyzed by capillary electrophoresis. All 4 replicates from each group were identical, and 1 cheese from each group was chosen to represent the whole group. Identification of the peaks was based on previous findings (Andersen, 2009; Ardö et al., 2017 ): $1=$ para-K-CN, $2=\gamma_{2}$ - $\mathrm{CN}, 3$

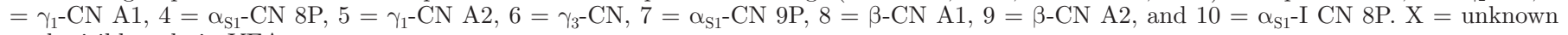
peak visible only in YEA. 
to-casein ratio had been adjusted, these differences in $\alpha_{\mathrm{S1}}$-CN degradation might have been less. In the present experiment, rennet was added per volume of milk as that is the normal practice in the Norwegian cheese industry (there are normally very small variations in protein and casein content of milk). However, when using new feed sources that might alter the casein content of the milk, it may be important for the cheese industry to adjust the amount of rennet according to the content of casein in milk to make sure that the rennet-to-casein ratio is constant and thereby standardize the initial proteolysis of $\alpha_{\mathrm{S}_{1}} \mathrm{CN}$ in the produced cheese.

It is well known that proteolysis in cheese is important and decisive for texture development in cheese, and the differences we observed in the proteolysis pat- tern can explain why the sensory attributes related to texture explained most of the variation between the cheeses. Further work is needed to gain more knowledge about how degradation of specific proteins and peptides influences the development of texture during cheese ripening. The SBM cheeses had a significantly higher intensity of sour taste compared with the YEA cheeses, which may be explained by the higher concentrations of the FAA histidine, glutamic acid, and aspartic acid, which can contribute to a sour taste (Kilcawley, 2017).

Most LAB are auxotrophic for several AA (Christiansen et al., 2008), and to grow and fulfil their nutritional requirement they degrade casein to small peptides and AA. The SBM cheeses had a higher total concentration of FAA, and, together with a significantly higher
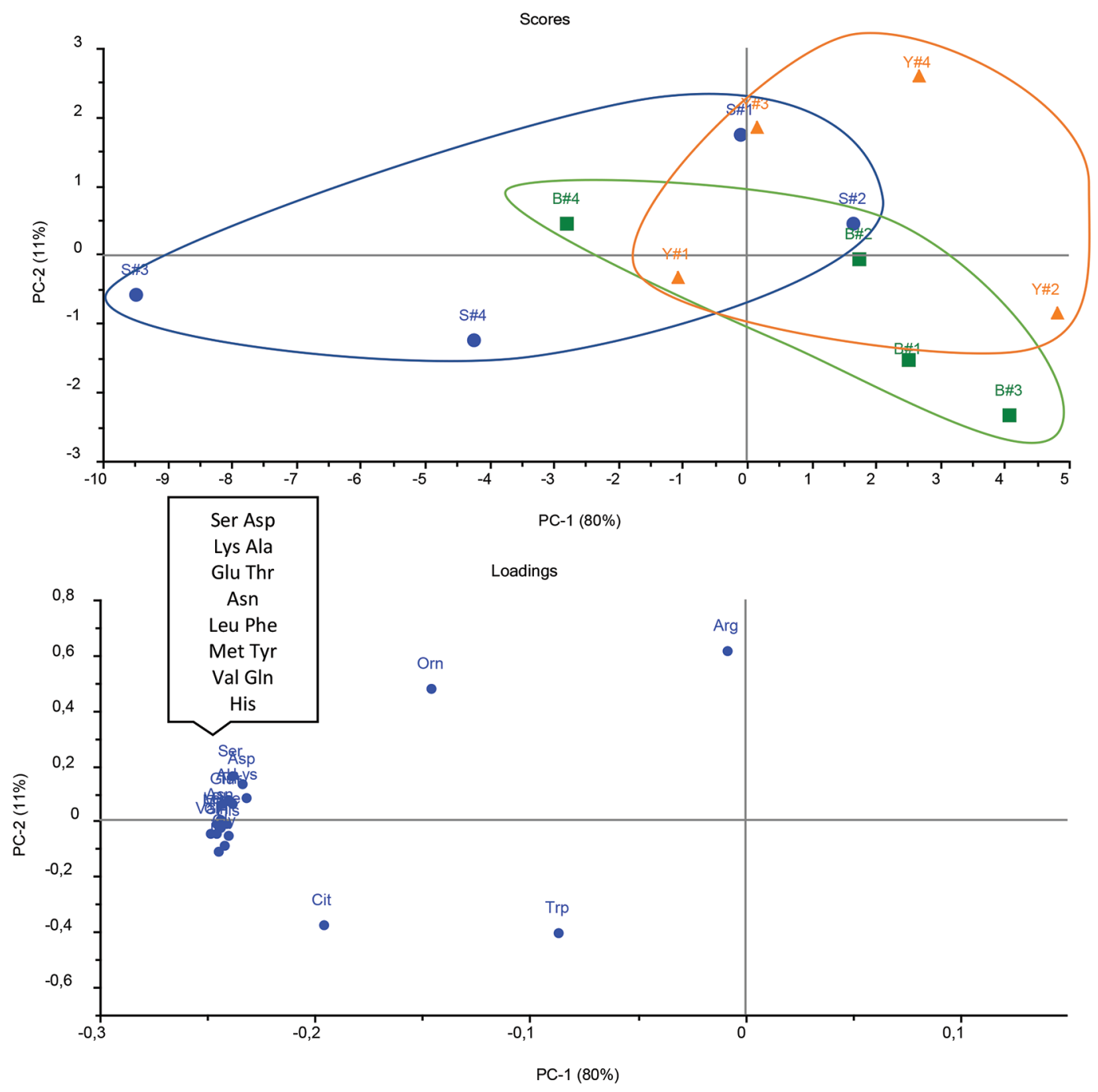

Figure 3. (A) Scores and (B) loadings of the principal component analysis of free AA in cheeses after 15 wk of ripening. The letter represents the concentrate feed treatment $(\mathrm{B}=$ barley; $\mathrm{Y}=$ yeast; $\mathrm{S}=$ soybean meal), and the number after each letter indicates which replicate (cheeses 1 and 2 within the same diet group were made on cheesemaking d 1, and cheeses 3 and 4 were made on cheesemaking d 2). Principal components (PC) 1 and 2 explain 80 and $11 \%$ of the variation, respectively. 


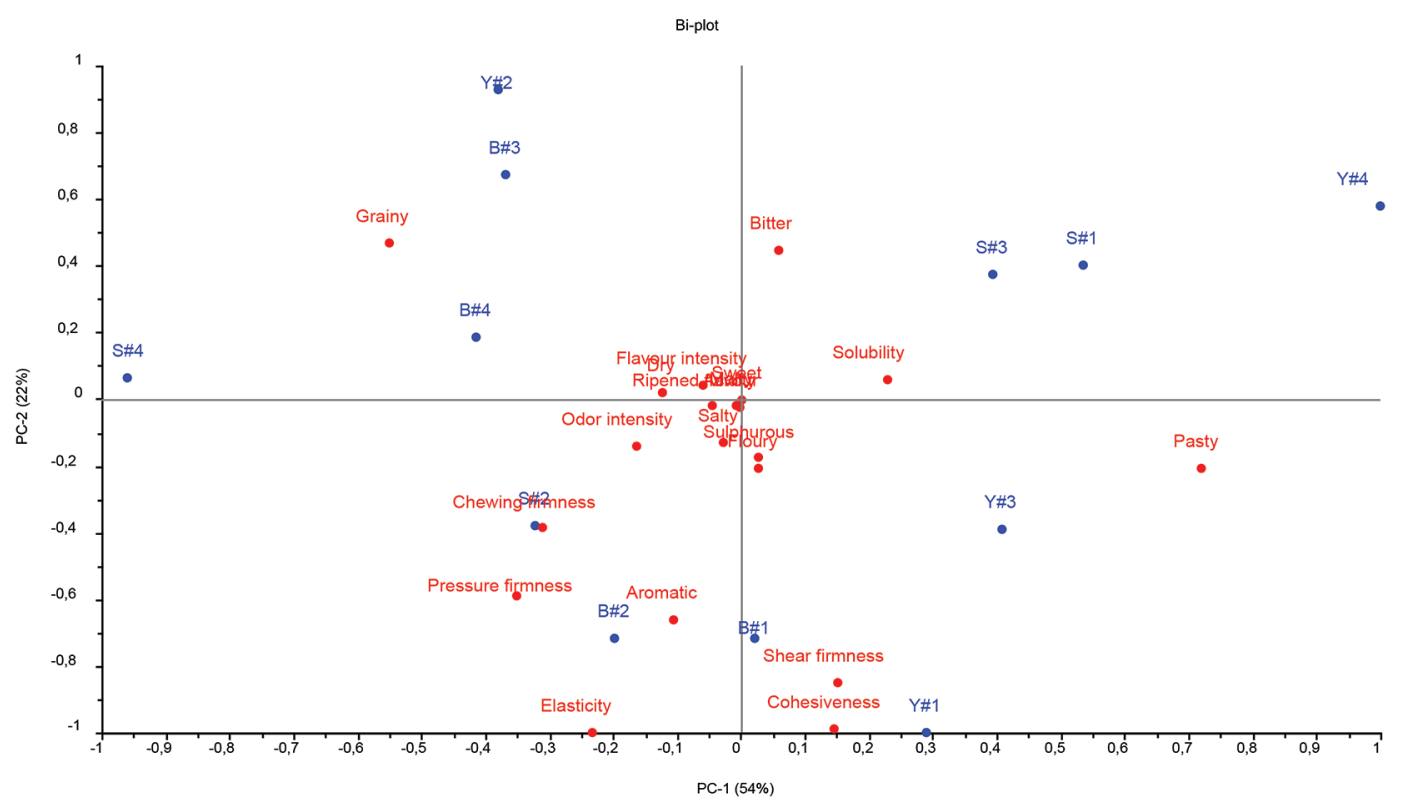

Figure 4. Principal component analysis of sensory analysis in cheese after 11 to $13 \mathrm{wk}$ of ripening. The letter represents the concentrate feed treatment $(\mathrm{B}=$ barley; $\mathrm{Y}=$ yeast; $\mathrm{S}=$ soybean meal), and the number after each letter indicates which replicate (cheeses 1 and 2 within the same diet group were made on cheesemaking $\mathrm{d} 1$, and cheeses 3 and 4 were made on cheesemaking d 2). Principal components (PC) 1 and 2 explain 54 and $22 \%$ of the variation, respectively. The experimental groups are shown in different gray colors.

content of DL-pyroglutamic acid, this indicates that the overall ripening occurred somewhat faster in these cheeses. Moreover, the somewhat higher content of Lactococcus spp. observed in the SBM cheeses both 24 $\mathrm{h}$ after starter addition and after $15 \mathrm{wk}$ of ripening may have contributed to increased enzymatic activity and may thereby explain the faster ripening in these cheeses. After 15 wk of ripening, DL-pyroglutamic acid was the only organic acid that was significantly different between the cheeses. Pyroglutamic acid can be formed from either glutamic acid or glutamine, where the FAA cyclizes from a lactam (Tschager and Jager, 1988; RCSB PDB, 2020). The SBM cheeses obtained a higher content of both glutamic acid and glutamine while also having a significantly higher concentration of DL-pyroglutamic acid. This supports the suggestion that ripening proceeded faster in the SBM cheeses. Pyroglutamic acid is a common compound in many cheese varieties, but it is particularly present in long-ripened cheeses such as Grana Padano and Parmigiano Reggiano. Mucchetti et al. (2000) found that the concentration of pyroglutamic acid was positively correlated with the ripening time of Grana Padano cheeses. Most likely, variations in the microbiota of the cheese influence the content of DL-pyroglutamic acid (Mucchetti et al., 2002). Nevertheless, in this experiment all other factors except the protein source in the concentrate feed were held constant during cheese production. A mesophilic starter culture was used, and the cheese milk was pasteurized at $72^{\circ} \mathrm{C}$ for $15 \mathrm{~s}$. Moreover, as shown by the $16 \mathrm{~S}$ rDNA sequencing made after 15 wk of ripening to map the microbiota, no differences were observed between the cheeses, and it is therefore not likely that differences in the microbiota could explain the differences in ripening between the SBM, YEA, and BAR cheeses. Based on these observations, it seems that the development of pyroglutamic acid during cheese ripening is dependent not only on the starter culture or the raw milk microflora but also on factors influenced by the milk and the concentrate feed that the dairy cow has been fed.

Further work is required to reveal the influence of feed on cheese ripening. A study by Inglingstad et al. (2016) tested the effect of adding saturated and unsaturated lipids in concentrate feed to Norwegian goats on milk composition, coagulation properties, and cheese quality. The cheese made with milk from goats fed concentrate with saturated fat had a higher total solids content compared with cheese made with milk from goats fed concentrate with unsaturated fat. They also uncovered a faster ripening and a better texture in cheese made with milk from goats that received concentrate supplemented with saturated lipids. These results show that the feed may influence the ripening of the cheese.

Even if the different concentrate feeds seemed to affect the ripening of cheese in this study, the effect on individual sensory attributes was minor. Nevertheless, 

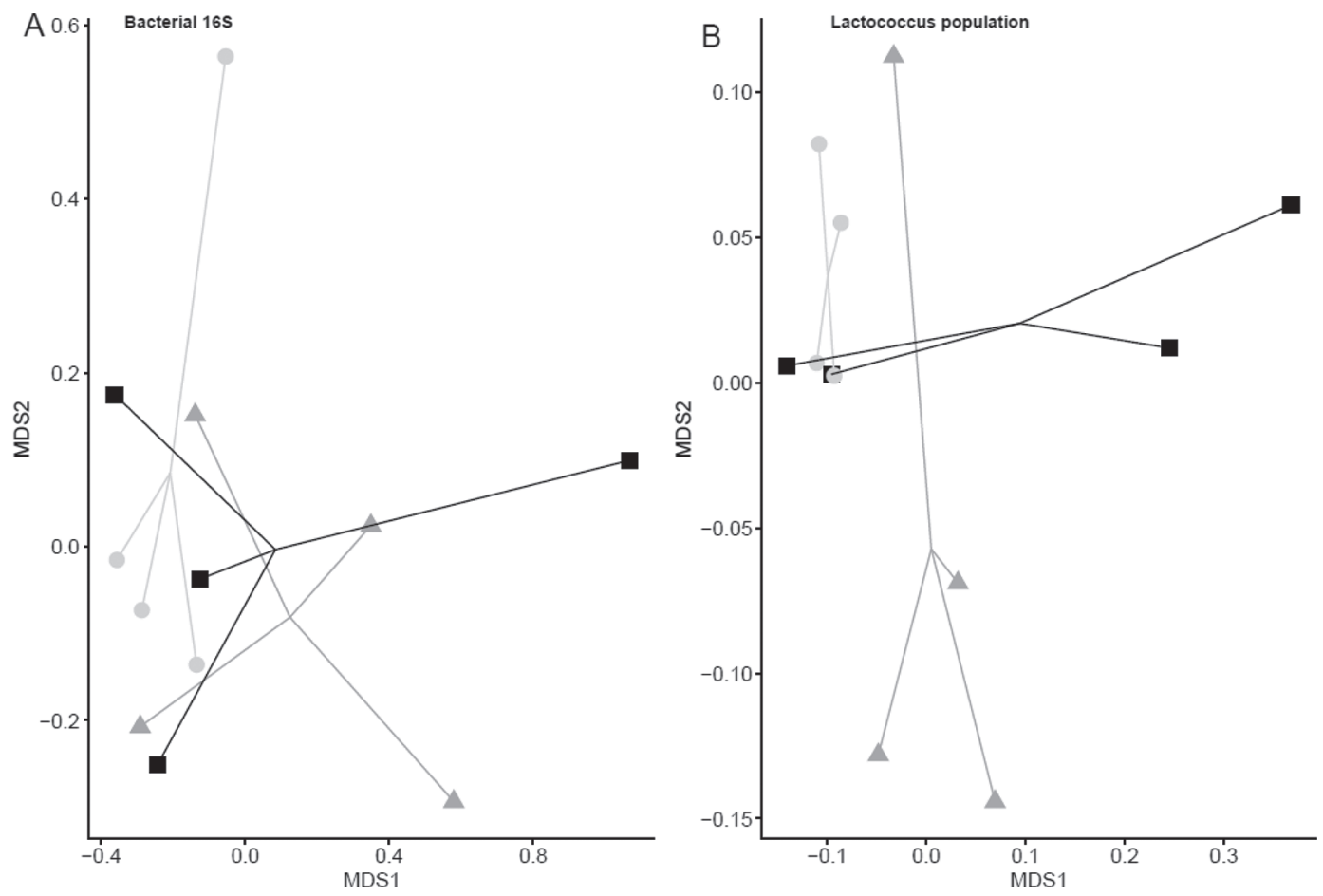

Figure 5. Microbiota of cheeses after 15 wk of ripening using nonmetric multidimensional scaling (MDS) of (A) microbial composition (bacteria $16 \mathrm{~S}$, stress value $=0.02$ ) and $(\mathrm{B})$ the Lactococcus population (obtained from amplicon sequencing of the lactococcal epsD gene, stress value $=0.01) . \bullet=$ barley; $\boldsymbol{\Delta}=$ YEA; $\mathbf{\square}=\mathrm{SBM}$.

these results show that a switch is possible from a barley- or soy-based concentrate (mostly used in Norway today) to a more novel and sustainable yeast-based concentrate while maintaining the overall quality of the Gouda-type cheese produced.

The robustness of the experiment was tested by making cheese with milk from the same group of cows over 2 cheese-making days, thereby using different milk, which is more applicable to industrial production. However, this led to quite high standard deviations for some of the milk and cheese variables; this could be one reason why we often see a trend in the results but few significant differences. The cheeses were ripened for only 15 wk when analyzed, and we could possibly expect a higher deviation between the cheeses if they were ripened for a longer time. However, the bulk amount of cheese produced in Norway is sold after 3 mo of ripening (J. Øyaas, TINE SA, Trondheim, Norway, personal communication); therefore, the results obtained in this experiment are very relevant for the industry.

\section{CONCLUSIONS}

The main finding in this experiment was that the SBM cheeses seemed to have a somewhat faster ripening process than the YEA and BAR cheeses as indicated by the significantly higher concentration of DL-pyroglutamic acid and a higher content of FAA after 15 wk of ripening. However, beyond these results, there are few clear differences between the cheeses, and the sensory analysis did not show any clear indications that support our interpretation of faster ripening in the SBM cheeses. All cheeses were judged to be of good quality, and these results thus suggest that the yeast C. utilis can replace soy or be added as a supplement to barley in concentrate feed for dairy cows without compromising the quality of cheese.

\section{ACKNOWLEDGMENTS}

The authors thank Ola Tjåland at the Food Pilot Plant (NMBU, Ås, Norway) for assistance during cheese manufacture; Helene Tynes Farstad at the Animal Production and Experimental Unit (NMBU) for cooperation with managing the milk collection logistics; TINE S/A (Oslo, Norway) for analyzing crude composition of milk and sensory analysis; and May Helene Aaberg, Kari Olsen, and Ahmed Abdelghani (NMBU) for technical assistance during sampling and analysis. This study was funded by Foods of Norway, Centre for Research-Based Innovation (Research Council of Norway, RCN, Olso; grant no. 237841/030). This re- 
search used the Food Pilot Plant facilities at Norwegian University of Life Sciences (Ås, Norway) that received a grant from RCN (grant 208674/F50). The authors have not stated any conflicts of interest.

\section{REFERENCES}

Andersen, L. T. 2009. A chemical and sensory study of water-soluble compounds in mature Cheddar cheese with savory flavour. $\mathrm{PhD}$ Thesis. Department of Food Science, Faculty of Life Sciences, University of Copenhagen, Copenhagen, Denmark.

Animalia. 2019. Hva spiser husdyra? Accessed Apr. 23, 2020. https: //www.animalia.no/no/samfunn/kjottproduksjon/hva-spiser -husdyra/.

Ardö, Y., P. L. McSweeney, A. A. Magboul, V. K. Upadhyay, and P. F. Fox. 2017. Biochemistry of cheese ripening: Proteolysis. Pages 445-482 in Cheese Chemistry, Physics and Microbiology. P. L. H. McSweeney, P. F. Fox, P. D. Cotter, and D. W. Everett, ed. Academic Press, San Diego, CA.

Christiansen, J. K., J. E. Hughes, D. L. Welker, B. T. Rodríguez, J. L. Steele, and J. R. Broadbent. 2008. Phenotypic and genotypic analysis of amino acid auxotrophy in Lactobacillus helveticus CNRZ 32. Appl. Environ. Microbiol. 74:416-423. https://doi.org/ 10.1128/AEM.01174-07.

de Visser, C. L. M., R. Schreuder, and F. Stoddard. 2014. The EU's dependency on soya bean import for the animal feed industry and potential for EU produced alternatives. Oilseeds and fats. Crops Lipids 21:D407. https://doi.org/10.1051/ocl/2014021.

Eurostat. 2019. Agriculture, forestry and fishery statistics. Accessed Jun. 25, 2020. https://ec.europa.eu/eurostat/documents/ 3217494/10317767/KS-FK-19-001-EN-N.pdf/742d3fd2-961e-68c1 $-47 \mathrm{~d} 0-11 \mathrm{cf} 30 \mathrm{~b} 11489$.

FCRN Foodsource. 2020. Soy: Food, feed and land use change. Accessed Apr. 23, 2020. https://www.foodsource.org.uk/building -blocks/soy-food-feed-and-land-use-change.

Ferreira, A. C., J. F. Vieira, A. M. Barbosa, T. M. Silva, L. R. Bezerra, N. G. Nascimento Jr., J. E. de Freitas Jr., S. M. P. L. Jaeger, P. A. Oliveira, and R. L. Oliveira. 2017. Effect of replacing ground corn and soybean meal with licuri cake on the performance, digestibility, nitrogen metabolism and ingestive behavior in lactating dairy cows. Animal 11:1957-1965. https://doi.org/10.1017/ S175173111700074X.

Fox, P. F., T. M. Cogan, and T. P. Guinee. 2017. Factors that affect the quality of cheese. Pages 617-640 in Cheese Chemistry, Physics and Microbiology. P. L. H. McSweeney, P. F. Fox, P. D. Cotter, and D. W. Everett, ed. Academic Press, San Diego, CA.

Inglingstad, R., M. Eknæs, L. Brunborg, T. Mestawet, T. Devold, G. Vegarud, and S. Skeie. 2016. Norwegian goat milk composition and cheese quality: The influence of lipid supplemented concentrate and lactation stage. Int. Dairy J. 56:13-21. https://doi.org/ 10.1016/j.idairyj.2015.12.010.

International Dairy Federation. 1993. Determination of the nitrogen (Kjeldahl method) and calculation of the crude protein content. IDF Standard 20B. International Dairy Federation, Brussels, Belgium.

International Dairy Federation. 1995. Milk and milk products: Guidance on sampling. Standard 50C. International Dairy Federation, Brussels, Belgium.

ISO. 1988. Sensory analysis - General guidance for the design of test rooms. ISO Standard 8589. International Organization for Standardization, Geneva, Switzerland.

ISO. 1992. Sensory analysis-Vocabulary. ISO Standard 5492. International Organization for Standardization, Geneva, Switzerland.

ISO. 2003. Sensory analysis - Guidelines for the use of quantitative response scales. ISO Standard 4121. International Organization for Standardization, Geneva, Switzerland.

Jørgensen, C. E., R. K. Abrahamsen, E.-O. Rukke, A.-G. Johansen, R. B. Schüller, and S. B. Skeie. 2016. Optimization of protein fractionation by skim milk microfiltration: Choice of ceramic membrane pore size and filtration temperature. J. Dairy Sci. 99:61646179. https://doi.org/10.3168/jds.2016-11090.

Ketto, I. A., T. M. Knutsen, J. Øyaas, B. Heringstad, T. Ådnøy, T. G. Devold, and S. Skeie. 2017. Effects of milk protein polymorphism and composition, casein micelle size and salt distribution on the milk coagulation properties in Norwegian Red cattle. Int. Dairy J. 70:55-64. https://doi.org/10.1016/j.idairyj.2016.10.010.

Kilcawley, K. N. 2017. Cheese flavour. Pages 443-474 in Fundamentals of Cheese Science. 2nd ed. P. F. Fox, T. P. Guinee, T. M. Cogan, and P. L. H. McSweeney, ed. Springer, New York, NY.

Kraggerud, H., S. Skeie, M. Høy, L. Røkke, and R. Abrahamsen. 2008. Season and ripening temperature influence fatty acid composition and sensory properties of semi-hard cheese during maturation. Int. Dairy J. 18:801-810. https://doi.org/10.1016/j.idairyj.2007.11 .003 .

Lapeña, D., G. Kosa, L. D. Hansen, L. T. Mydland, V. Passoth, S. J. Horn, and V. G. Eijsink. 2020. Production and characterization of yeasts grown on media composed of spruce-derived sugars and protein hydrolysates from chicken by-products. Microb. Cell Fact. 19:19. https://doi.org/10.1186/s12934-020-1287-6.

Manthey, A. K., K. Kalscheur, A. Garcia, and K. Mjoun. 2016. Lactation performance of dairy cows fed yeast-derived microbial protein in low-and high-forage diets. J. Dairy Sci. 99:2775-2787. https:// doi.org/10.3168/jds.2015-10014.

Martinovic, A., K. M. Moe, E. Romeih, B. Aideh, F. K. Vogensen, H. Østlie, and S. Skeie. 2013. Growth of adjunct Lactobacillus casei in Cheddar cheese differing in milk fat globule membrane components. Int. Dairy J. 31:70-82. https://doi.org/10.1016/j.idairyj .2013.02.009.

Mucchetti, G., F. Locci, M. Gatti, E. Neviani, F. Addeo, A. Dossena, and R. Marchelli. 2000. Pyroglutamic acid in cheese: Presense, origin, and correlation with ripening time of Grana Padano cheese. J. Dairy Sci. 83:659-665. https://doi.org/10.3168/jds.S0022 $-0302(00) 74926-5$.

Mucchetti, G., F. Locci, P. Massara, R. Vitale, and E. Neviani. 2002. Production of pyroglutamic acid by thermophilic lactic acid bacteria in hard-cooked mini-cheeses. J. Dairy Sci. 85:2489-2496. https: //doi.org/10.3168/jds.S0022-0302(02)74331-2.

Neal, K., J. Eun, A. Young, K. Mjoun, and J. Hall. 2014. Feeding protein supplements in alfalfa hay-based lactation diets improves nutrient utilization, lactational performance, and feed efficiency of dairy cows. J. Dairy Sci. 97:7716-7728. https://doi.org/10.3168/ jds.2014-8033.

Øverland, M., and A. Skrede. 2017. Yeast derived from lignocellulosic biomass as a sustainable feed resource for use in aquaculture. J. Sci. Food Agric. 97:733-742. https://doi.org/10.1002/jsfa.8007.

Paulson, J. N., O. C. Stine, H. C. Bravo, and M. Pop. 2013. Differential abundance analysis for microbial marker-gene surveys. Nat. Methods 10:1200-1202. https://doi.org/10.1038/nmeth.2658.

Porcellato, D., and S. B. Skeie. 2016. Bacterial dynamics and functional analysis of microbial metagenomes during ripening of Dutchtype cheese. Int. Dairy J. 61:182-188. https://doi.org/10.1016/j .idairyj.2016.05.005.

RCSB PDB (Research Collaboratory for Structural Bioinformatics Protein Data Bank). 2020. PDB ID DB11245. Accessed Feb. 19, 2020. http://www.rcsb.org/ligand/PCA.

Sabbia, J. A., K. Kalscheur, A. Garcia, A. Gehman, and J. Tricarico. 2012. Soybean meal substitution with a yeast-derived microbial protein source in dairy cow diets. J. Dairy Sci. 95:5888-5900. https://doi.org/10.3168/jds.2011-5237.

Sankarlal, V. M., E. Testroet, D. Beitz, and S. Clark. 2015. Dried distillers grains with solubles do not always cause late blowing in baby Swiss cheese. J. Dairy Sci. 98:8545-8553. https://doi.org/10 .3168/jds.2015-9983.

Skeie, S. B., M. Håland, I. Thorsen, J. Narvhus, and D. Porcellato. 2019. Bulk tank raw milk microbiota differs within and between farms: A moving goalpost challenging quality control. J. Dairy Sci. 102:1959-1971. https://doi.org/10.3168/jds.2017-14083. 
Skeie, S., A. Kieronczyk, S. Eidet, M. Reitan, K. Olsen, and H. Østlie. 2008. Interaction between starter bacteria and adjunct Lactobacillus plantarum INF15D on the degradation of citrate, asparagine and aspartate in a washed-curd cheese. Int. Dairy J. 18:169-177. https://doi.org/10.1016/j.idairyj.2007.09.002

Statistisk Sentralbyrå. 2019. Land use and land cover. Accessed Jun. 10, 2020. https://www.ssb.no/en/natur-og-miljo/statistikker/ arealstat.

Sutton, J. 1989. Altering milk composition by feeding. J. Dairy Sci. 72:2801-2814. https://doi.org/10.3168/jds.S0022-0302(89)79426

Testroet, E. D., D. Beitz, M. O'Neil, A. Mueller, H. Ramirez-Ramirez, and S. Clark. 2018. Feeding reduced-fat dried distillers grains with solubles to lactating Holstein dairy cows does not alter milk composition or cause late blowing in cheese. J. Dairy Sci. 101:58385850. https://doi.org/10.3168/jds.2017-13699.

Tschager, E., and H. Jager. 1988. Pyroglutamic acid in milk and milk products with specific consideration of cheese. Milchwirtsch Berichte 95:79-83.

United Nations. 2017. World population projected to reach 9.8 billion in 2050, and 11.2 billion in 2100. Accessed May 20, 2020. https: //www.un.org/development/desa/en/news/population/world -population-prospects-2017.html.

Volden, H. 2011. NorFor: The Nordic feed evaluation system. Vol. 30. Wageningen Academic Publishers, Wageningen, the Netherlands. 